Brit. J. vener. Dis. (1962), 38, 75.

\title{
TREATMENT OF BALANITIS XEROTICA OBLITERANS WITH HYDROCORTISONE INJECTIONS*
}

\author{
BY \\ R. D. CATTERALL \\ The General Infirmary, Leeds \\ AND \\ J. K. OATES \\ Addenbrooke's Hospital, Cambridge
}

Lichen sclerosus et atrophicus was first described by Hallopeau (1887), who regarded it as a variant of lichen planus. Ormsby (1910), however, considered it to be a separate disease entity. Stühmer (1928) used the term "balanitis xerotica obliterans" to describe a case in which there was progressive sclerosis and atrophy of the glans penis and preputial remains following an operation for congenital phimosis. Balanitis xerotica obliterans was considered to be a localized form of lichen sclerosus et atrophicus by Laymon and Freeman (1944), who described six cases which presented with involvement of the penis. On detailed examination of the rest of the skin they found involvement of the trunk or limbs in four cases. Laymon (1951) described two forms of lichen sclerosus et atrophicus of the male genitalia. In the first group there were isolated papules on the shaft of the penis and prepuce which sometimes coalesced to form a constricting band, and secondly there were cases with white atrophic plaques on the glans and stenosis of the urethral meatus.

Lichen sclerosus et atrophicus also occurs on the genitalia in women. This condition has been thoroughly described by Wallace and Whimster (1951). The disease is also well known in female children. Kindler (1953) reported eight cases in girls with anogenital lesions, but only one had lesions elsewhere on the body.

The condition has to be distinguished from lichen planus, leucoderma, scleroderma, and leucoplakia. The histological features of lichen sclerosus et atrophicus and balanitis xerotica obliterans are essentially the same. There is slight acanthosis of the epidermis with homogenization of the collagen of the upper corium and a mild round cell infiltration of the lower part of the corium.

During the past few years our attention has been drawn to this condition as it affects the male genitalia. It appears to be more common than was formerly supposed and frequently presents in two ways. There may be plaques of white sclerotic tissue on the glans penis or on the prepuce with telangiectases, and, in

* Paper read at M.S.S.V.D. meeting in Paris on May 12, 1961. some cases, white fibrous tissue surrounds the external urinary meatus causing stenosis. This is the classical type of balanitis xerotica obliterans and the condition is well known and is usually recognized. However, the disease appears to occur even more frequently as a peri-meatal collar of white fibrous tissue involving the external urinary meatus, with induration and extension along the terminal part of the urethra. In the acute stage the lips of the meatus are dead white, indurated, and swollen, and surrounded by an inflammatory halo, which tends to disappear spontaneously. More advanced cases show obliteration of the lips of the meatus with various degrees of constriction. Urethroscopy often reveals white plaques in the fossa navicularis and in the anterior urethra, and the urethral walls can often be felt to be thickened and indurated on palpation.

\section{Cases Studied}

During the past five years, 41 cases of balanitis xerotica obliterans have been studied. The ages of the patients ranged from 21 to 55, but the majority were between 21 and 35 years of age. Thirty of the patients were married. Fifteen of them had noticed the lesions on the penis and sought advice because they were afraid that they had a venereal disease. 23 first presented with urethral discharge. Seventeen had suffered recurrent attacks of non-gonococcal urethritis and six were found to have gonorrhoea. Twelve patients had predominantly urinary symptoms. In six there was marked difficulty in micturition with a poor urinary stream. Two cases presented with acute retention of urine. The other four patients had recurrent attacks of cystitis, which appeared to be secondary to marked meatal stenosis. The presenting symptoms are listed in Table I.

TABLE I

PRESENTING SYMPTOMS OF BALANITIS XEROTICA OBLITERANS

\begin{tabular}{|c|c|c|c|c|c|}
\hline Lesion Noted by the & Patient & $\cdots$ & $\cdots$ & $\cdots$ & 15 \\
\hline Urethral Discharge & .. & $\cdots$ & $\cdots$ & .. & 23 \\
\hline Difficulty with Mictu & ition & $\cdots$ & . & . & 6 \\
\hline Retention of Urine & $\cdots$ & $\cdots$ & . & . & 2 \\
\hline Cystitis .. & . & . & .. & .. & 4 \\
\hline
\end{tabular}


Of the 41 patients, fourteen had typical signs with white fibrous tissue surrounding the meatus and sclerotic tissue on the glans. Telangiectases occurred in six cases. There was involvement of the prepuce in five cases, and three later developed phimosis and circumcision had to be performed. Plaques of lichen sclerosus et atrophicus were found on the skin of the trunk in four of these patients.

In the remaining 27 patients, the sclerotic tissue was limited to a peri-meatal collar of white tissue often extending into the fossa navicularis; 21 of these patients were circumcised and six uncircumcised. Two patients were found to have lesions of lichen sclerosus et atrophicus on the shoulders and abdomen. Biopsy of the peri-meatal tissue in two cases showed changes typical of lichen sclerosus et atrophicus.

We have recently observed a case in a boy aged 7 years who developed attacks of balano-posthitis and whose prepuce became irretractable. There was no peri-meatal involvement. The patient was circumcised and histological section showed changes typical of balanitis xerotica obliterans.

In four cases the peri-meatal sclerosis was observed to disappear spontaneously without treatment in from 6 to 9 months. In the remainder, repeated attacks of urethritis and urinary infection tended to occur unless the meatal stenosis was corrected. One patient developed chronic pyelonephritis and another was found to have hydronephrosis following long-standing meatal stenosis.

Six typical cases are shown in the Figure (opposite).

\section{Treatment and Results}

No specific therapy is available, as the aetiology of lichen sclerosus et atrophicus is unknown. Various forms of therapy have been recommended in the past, including androgen and oestrogen ointments and vitamin $\mathrm{E}$ parenterally. There is no convincing evidence that any of these is effective.

In our experience, mild cases, where the meatal stenosis is not severe, respond well to regular simple dilatation of the meatus with well-lubricated straight metal sounds. In more severe cases, the effect of dilatation was only temporary and repeated and prolonged instrumentation was required to keep the meatus open. Meatotomy gave poor results in the four patients in whom it was tried, the meatus becoming re-stenosed a few months after operation.

Stenosis of the meatus in 21 patients was treated with weekly injections of 1 to $2 \mathrm{ml}$. of a suspension of hydrocortisone acetate into the peri-meatal and peri-urethral tissues. The urethra and glans penis were anaesthetized by the application of "Xylocaine" jelly for 10 minutes before the injection. The hydrocortisone was infiltrated into the peri-meatal and peri-urethral tissues slowly, using a very fine hypodermic needle. Following the injection the meatus was dilated with straight sounds. Six to eight injections at weekly or bi-weekly intervals were usually required. The results are shown in Table II.

TABLE II

RESULTS OF TREATMENT WITH HYDROCORTISONE

\begin{tabular}{|c|c|c|c|c|c|c|}
\hline \multicolumn{2}{|c|}{ No. of Patients Treated } & . & .. & . & . & 21 \\
\hline \multirow{5}{*}{ Result } & Cured, & . & .. & . & . & 5 \\
\hline & \multicolumn{3}{|c|}{ Great Improvement } & . & . & 6 \\
\hline & \multicolumn{3}{|c|}{ Moderate Improvement } & . & . & 4 \\
\hline & Relapse & . & .. & . & . & 5 \\
\hline & No Effe & . & .. & .. & .. & 1 \\
\hline
\end{tabular}

Improvement occurred in twenty of the 21 cases. Complete cure appears to have resulted in five and no evidence of meatal sclerosis was seen in any of them 6 months after treatment. In one patient no improvement occurred and the condition progressed despite repeated hydrocortisone injections. Six patients required no further urethral dilatations during a follow-up period of 1 year, and in four others the frequency of dilatation was greatly reduced, usually to as little as once or twice a year. In the remaining five cases there was considerable immediate improvement but relapse occurred in all of them during the period of follow up. No untoward effects of the injections were observed, although a small number experienced pain on micturition for several hours following the injection.

\section{Summary and Conclusions}

A series of 41 cases of balanitis xerotica obliterans involving the external urinary meatus is described. The condition is considered to be a localized manifestation of lichen sclerosus et atrophicus. The symptoms and signs are discussed in detail.

In mild cases satisfactory results were obtained by regular dilatation of the external urinary meatus with straight metal sounds. In more severe cases, the injection of 1 to $2 \mathrm{ml}$. of a suspension of hydrocortisone acetate into the peri-meatal and periurethral tissues under local anaesthesia, followed by dilatation of the meatus with straight sounds, gave promising results.

Of 21 patients treated by this method, five were apparently cured, six were greatly improved, and four moderately improved. Five patients relapsed after initial improvement and in one case the disease progressed despite repeated therapy.

\section{REFERENCES}

Hallopeau, H. (1887). Ann. Derm. Syph. (Paris), sér 2, $8,790$.

Kindler, T. (1953). Brit. J. Derm., 65, 269. 

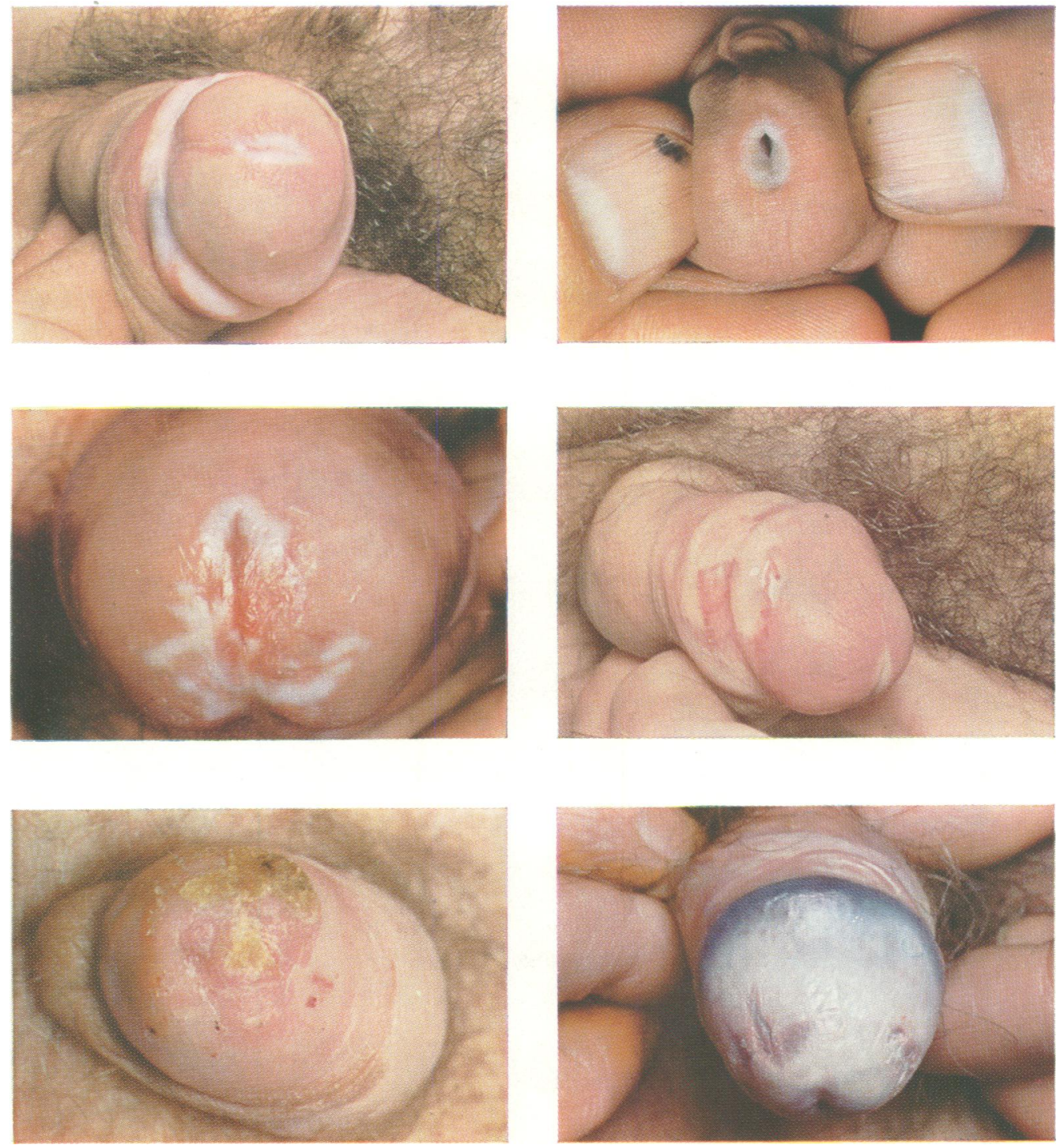

Figure.-Six examples of balanitis xerotica obliterans.

Face p. 76 
Laymon, C. W. (1951). A.M.A. Arch. Derm. Syph., 64, 620.

and Freeman, C. (1944). Arch. Derm. Syph. (Chicago), 49, 57.

Ormsby, O. S. (1910). J. cutan. Dis. (N.Y.), 28, 433.

Stühmer, A. (1928). Arch. Derm. Syph. (Berl.), 156, 613.

Wallace, H. J., and Whimster, I. W. (1951). Brit.J. Derm., 63,241 .

Traitement de la balanite xérotique oblitérante par injection d'hydrocortisone

RÉSUMÉ

On décrit 41 cas de balanite xérotique oblitérante du méat urinaire extérieur, maladie qui peut être regardée comme une manifestation locale du lichen sclérotique et atrophique. On particularise les signes et les symptômes. Dans les cas les moins sévères, il suffit de dilater le méat avec une sonde de métal droite. Dans les cas les plus sévères on a obtenu de bons résultats en injectant de 1 à $2 \mathrm{ml}$. d'une suspension d'acétate d'hydrocortisone dans les tissus autour du méat et de l'urètre sous anesthésie locale, et en dilatant ensuite le méat avec une sonde droite. Sur 21 malades traités de cette façon cinq guérirent, six se trouvèrent beaucoup mieux, et cinq un peu mieux. Cinq malades firent une rechute et un empira malgré que le traitment fût répété à plusieurs reprises. 